\title{
Does Medication-related Osteonecrosis of the Jaw Affect Maxillary Sinus Volume and Mucosal Thickness?
}

MRONJ Maksiller Sinüs Kalınlığını ve Sinüs Volümünü Etkiler mi?

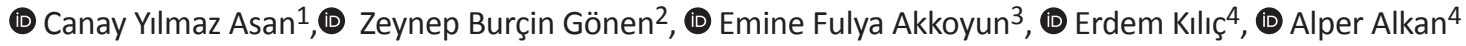 \\ ${ }^{1}$ Erciyes University Faculty of Dentistry, Department of Oral and Maxillofacial Surgery, Kayseri, Turkey \\ 2Erciyes University, Genome and Stem Cell Center, Kayseri, Turkey \\ ${ }^{3}$ Ministry of Health, Göztepe Oral and Dental Health Hospital, Clinic of Oral and Maxillofacial Surgery, İstanbul, Turkey \\ ${ }^{4}$ Bezmialem Vakıf University Faculty of Dentistry, Department of Oral and Maxillofacial Surgery, İstanbul Turkey
}

Keywords

Maxillary sinus, bisphosphonate, osteonecrosis

Anahtar Kelimeler

Maksiller sinüs, bifosfonatlar, osteonekroz

Received/Geliş Tarihi : 04.09.2018

Accepted/Kabul Tarihi : 30.11.2018

doi:10.4274/meandros.galenos.2018.44366

Address for Correspondence/Yazışma Adresi: Canay Yılmaz Asan DDS, PhD, Assistant

Professor,

Erciyes University Faculty of Dentistry,

Department of Oral and Maxillofacial Surgery, Kayseri, Turkey

Phone : +90 5331673238

E-mail :dtcanayasan@gmail.com

ORCID ID: orcid.org/0000-0001-9868-6415

(C) Meandros Medical and Dental Journal, Published by Galenos Publishing House.

This is article distributed under the terms of the

Creative Commons Attribution NonCommercial 4.0

International Licence (CC BY-NC 4.0).

\begin{abstract}
Objective: Bisphosphonates (BPs) are commonly prescribed drugs because of their antiresorptive effects. However, BPs may cause medication-related osteonecrosis of the jaw (MRONJ). This study aimed to compare the maxillary sinus volumes and mucosal thickening of patients with MRONJ and healthy patients.

Materials and Methods: This retrospective cohort study evaluated cone-beam computed tomography images of 54 maxillary sinuses in 27 patients. Patients were divided into three groups: group $1(n=8)$, patients with maxillary MRONJ; group 2 $(n=9)$, patients treated with BPs and had no maxillary osteonecrosis (study groups); and group $3(n=10)$, healthy individuals (control group). Maxillary sinus volumes and mucosal thickening were compared among the groups.

Results: No statistically significant difference in maxillary sinus volumes was found among the groups $(p=0.153)$. The mean mucosal thickening was $5.920 \pm 5.94 \mathrm{~mm}$ in group $1,1.718 \pm 2.58$ in group 2 and $1.265 \pm 0.83$ in group 3 . Mucosal thickening was prominent significantly in Group 1 ( $p=0.001)$.

Conclusion: BPs can affect oral soft tissues as well as hard tissues. The study results showed significant changes in maxillary sinus mucosal thickening in patients with maxillary MRONJ.
\end{abstract}

Öz

Amaç: Bifosfonatlar (BPs), antirezorptif etkilerinden dolayı sıklıkla tercih edilen ilaçlardır. Çenelerin ilaçlarla ilişkili osteonekrozu (MRONJ), BP'lerin bir komplikasyonudur. Bu çalışmanın amacı, MRONJ hastalarının maksiller sinüs volümleri ve mukozal kalınlıklarının, sağlıklı bireylerle karşılaştırılmasıdır.

Gereç ve Yöntemler: Bu çalışmada, 27 hastadaki 54 maksiller sinüse ait konik ışınlı bilgisayarlı tomografi görüntüleri değerlendirildi. Çalışmaya dahil edilen hastalar üç gruba ayrıldı. Çalışma grubu olarak belirlenen grup $1(n=8)$ maksillada MRONJ gelişen hastalardan; grup $2(n=9)$ BP kullanan ancak maksillada MRONJ gelişmeyen hastalardan oluşurken; kontrol grubu olan grup $3(n=10)$ sağlıklı bireylerden oluşmakta idi. Gruplar arasındaki sinüs volümleri ve mukoza kalınlaşmaları istatistiksel olarak karşılaştırıldı. 
Bulgular: Maksiller sinüs volümleri açısından gruplar arasında anlamlı bir farklılığa rastlanmadı $(p=0,15)$. Grup 1'in ortalama mukoza

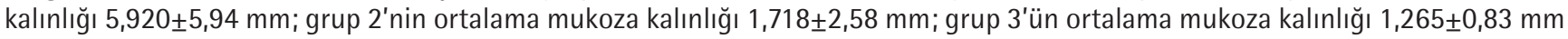
olarak ölçüldü ve grup 1'deki kalınlaşma istatistiksel olarak anlamlı bulundu ( $p=0,001)$.

Sonuç: BP'ler, oral sert dokuların yanı sıra, yumuşak dokuları da etkileyebilir. Bu çalışmanın sonuçlarına göre, maksillada MRONJ gelişen hastalarda belirgin mukozal kalınlaşma mevcuttur.

\section{Introduction}

Bisphosphonates (BPs) are antiresorptive drugs, which have intravenous (IV) and oral forms. IV BPs are generally used to manage cancer-related conditions including hypercalcemia of malignancy and bone metastases of solid tumors such as prostate cancer, breast cancer, and lung cancer, and for management of lytic lesions of multiple myeloma $(1,2)$. Furthermore, oral BPs are commonly prescribed for the management of osteoporosis and for treatment of less common skeletal diseases such as Paget's disease and Osteogenesis imperfecta $(3,4)$.

Common complications of BPs include acute renal failure, gastrointestinal disorders, hypocalcaemia, and Medication-related osteonecrosis of the jaw (MRONJ), which is described as exposed bone or bone that can be probed through an intraoral or extraoral fistula in the oral cavity that has been present more than 8 weeks with the history of BP administration and no previous radiation therapy to the jaws or obvious metastatic disease to the jaws $(1,5)$.

It was reported that the mandible is more frequently affected than the maxilla by BPs in several studies (6-9); however, there are few studies about involvement of maxillary sinuses, which are affected due to the maxillary MRONJ (10-12). Nevertheless it is still unknown how maxillary MRONJ affects maxillary sinus mucosa and volume and there is no study to compare them between patients who have MRONJ in maxilla and BPs treated and have not MRONJ.

\section{Materials and Methods}

\section{Sample Collections}

This retrospective cohort study followed the Declaration of Helsinki on Medical Protocol and Ethics; and the Local Ethics Committee of Erciyes University (Kayseri, Turkey) approved it with 2016/25 ethical number. Cone beam computed tomography (CBCT) images of the patients in three groups were investigated and patients treated with BPs for osteoporosis and malign metastatic tumors were included in this study. An informed consent was obtained from all patients.

\section{Patient Selection (Group 1 and 2)}

Patients in Group 1 were selected from patients who were diagnosed with maxillary MRONJ in Erciyes University Faculty of Dentistry, Department of Oral and Maxillofacial Surgery between 2011 and 2016 years. The diagnosis of MRONJ was established according to American Association of Oral and Maxillofacial Surgeons (AAOMS) criteria: (1) current or previous treatment with antiresorptive or antiangiogenic agents; (2) exposed bone or bone that can be probed through an intraoral or extraoral fistula in the maxillofacial region that has persisted for more than 8 weeks; and (3) no history of radiation therapy to the jaws or obvious metastatic disease to the jaws and these cases were classified into the four stages reported (1). Patients who treated with IV nitrogencontaining BPs (Zoledronate) and had images of CBCT of the maxilla-mandibular complex for the evaluation of osteonecrosis were chosen through those patients. CBCT scans without involving the whole maxillary sinuses bilaterally and patiens had sinus pathologies like rhino-sinusitis of the maxillary and other sinuses were excluded from the study. Patients in Group 2 were selected from IV BPs treated patients whose CBCT scans were taken for routine control due to the suspicion of osteonecrosis and had not MRONJ in maxillary region.

\section{Patient Selection (Group 3)}

In control group, ASA I and II patients who had no history of BP administration and maxillary sinus diseases with similar age and gender as study patients were selected through the patients who had CBCT images for evaluation of bone and surrounding anatomic structures for pre-implant surgery, impacted teeth, cysts or any other pathologies.

\section{Measurements}

All CBCT images were obtained in horizontal position (New Tom 5G, Verona, Italy). Scanning time was 18 seconds, voxel size was $0.3 \mathrm{~mm}$ and 
exposure time was 3.6 seconds. Mimics Software (Materialise $\mathrm{HQ}$, Leuven, Belgium) was preferred to produce DICOM format of the images. The data were reconstructed with slices at an interval of $0.25 \mathrm{~mm}$ and $15 \times 12$ field of view.

Bilateral maxillary sinuses were evaluated in axial, coronal and sagittal sections and the patient-specific Hounsfield units were used (Figure 1A, B). Maxillary sinus volumes were measured in " $\mathrm{mm}^{3}$ ".

Length of the sinus mucosa was measured from the coronal section from three different points vertically as "mm". The midpoint of the sinus floor was chosen for measurements to standardize all samples. Two other measurements $1.5 \mathrm{~mm}$ away from this point also performed and the mean value of these three measurements were calculated (Figure 2). The mean values of each sinus were compared between groups. The same researcher, who did not know the group of the patients, assessed all CBCT scans of study patients and controls.

\section{Statistical Analysis}

Data were analized with TURCOSA (Turcosa Analytics Ltd. Co., Turkey, www.turcosa.com.tr).
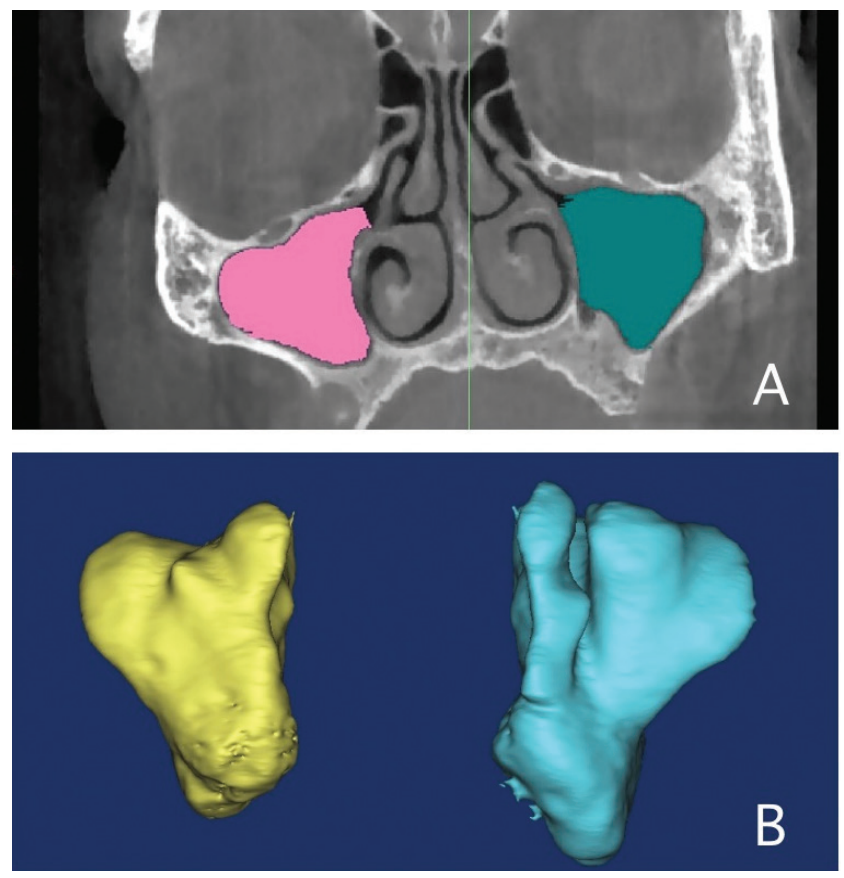

Figure 1. A) Selection of maxillary sinus borders as $\mathrm{mm}^{2}$ from coronal cone beam computed tomography section with the MIMIMCS software for three-dimensional (3D) evaluation of sinus volumes. B) 3D solid model of bilateral maxillary sinuses as $\mathrm{mm}^{3}$. This model was created after the investigation of sinuses from sagittal, coronal and axial sections
Normality of data was assessed using histogram, q-q plot and Shapiro-Wilk's test. Levene test was used to examine the homogeneity of variance. Oneway ANOVA was applied to compare the differences between groups and $p$ value $<0.05$ was considered as statistically significant.

\section{Results}

CBCT images of 54 maxillary sinuses in 27 patients were evaluated in this study. Group 1 consisted of 8 maxillary MRONJ patients. There were 9 patients in group 2 and 10 patients in group 3 . The mean age was $67 \pm 7$ in Group 1; $70 \pm 1$ in group 2; and $65 \pm 5$ in Group 3.

While three of patients were female (37.5\%) and five patients were male (62.5\%) in group 1; four patients were female (45\%) and five patients were male $(55 \%)$ in group 2 . All patients were given IV Zoledronic acid, and the mean duration time of BPs therapy was 35 months [minimum (min): 1 month, maximum (max): 60 months] in group 1 and 40 months (min: 12 months, max: 60 months) in group 2. The mainly reason of BPs therapy were prostate cancer ( $n=7$ patients) and also osteoporosis $(n=3)$ and breast cancer $(n=3)$ relatively. Also, four patients had been used BPs for other reasons such as lung cancer, pancreas cancer, multiple myeloma and endometrium cancer.

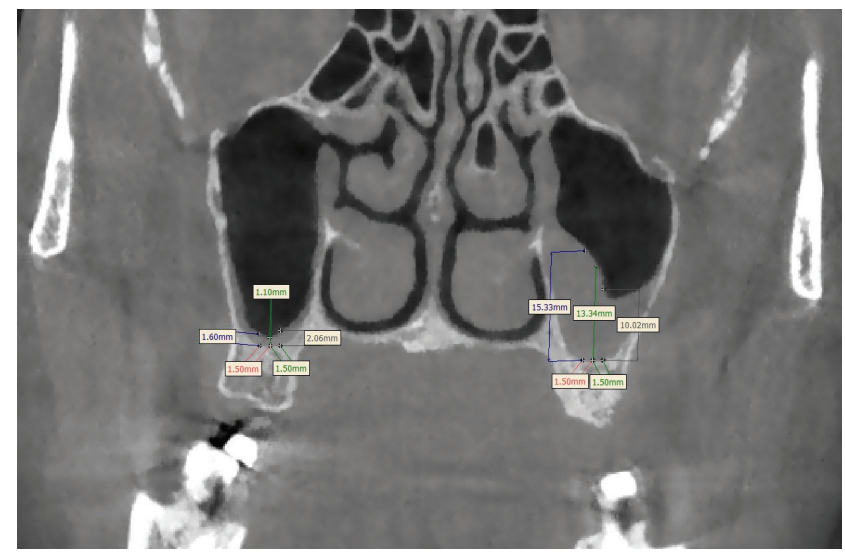

Figure 2. Measurement of mucosal thickening from three different points in a maxillary medication-related osteonecrosis of the jaw patient from coronal cone beam computed tomography image. After the selection of the midpoint of the sinus border, two vertical measurements were repeated from $1.5 \mathrm{~mm}$ distance (the blue and the gray lines). Note the thickening of the left sinus mucosa compared to the right one. Also note the irregular thickening of the left mucosal membrane 
Six patients had Stage 2 MRONJ and two patients had Stage 3 MRONJ in group 1 . The demographic data of the study group are shown in Table 1; and an intraoral view of a MRONJ patient was indicated (Figure 3 ).

The mean maxillary sinus volume was $9700 \mathrm{~mm}^{3}$ (min: 127, max: $20.662 \mathrm{~mm}^{3}$ ) in group 1; $11.498 \mathrm{~mm}^{3}$ ( $\min : 5541, \max : 18.210 \mathrm{~mm}^{3}$ ) in group 2 and 13.114 $\mathrm{mm}^{3}$ (min: 4165, max: $24.733 \mathrm{~mm}^{3}$ ) in the control

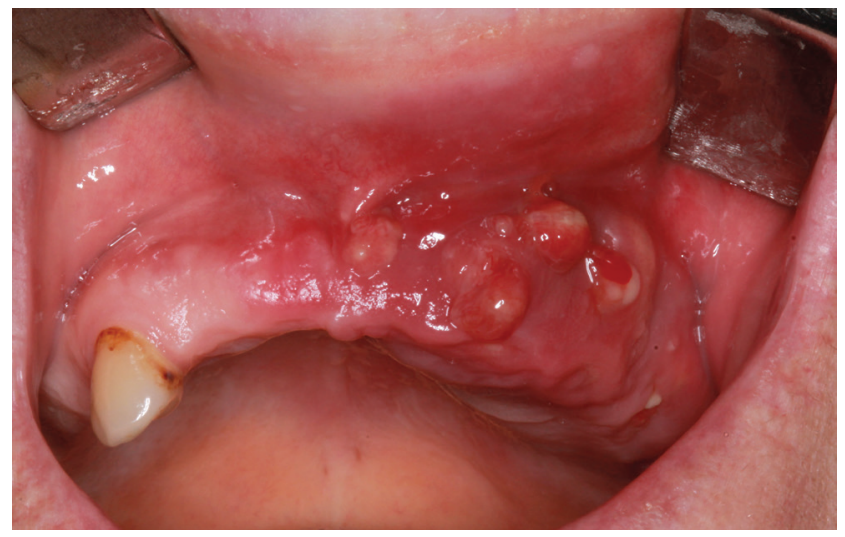

Figure 3. Intraoral view of the stage II medication-related osteonecrosis of the jaw in a patient in group 1 . The gingiva was inflamed and there were a lot of fistula formation with pus drainage group. There was no statistically significant difference between groups $(p=0.153)$ according to maxillary sinus volumes (Table 2 ).

Mucosal thickening was prominent and statistically significantly in group 1 compared to group $3(p=0.021)$ and group $2(p=0.049)$. The mean mucosal thickness was $5.92 \mathrm{~mm}$ (min: 0.38, max: $21.62 \mathrm{~mm}$ ) in group 1; $1.71 \mathrm{~mm}$ (min:0.30, max: 10.68) in group 2 and $1.26 \mathrm{~mm}$ (min: 0.30 , max: $3.21 \mathrm{~mm}$ ) in group 3. Four patients have mucosal thickening above $10 \mathrm{~mm}$ and two patients have thickening above $5 \mathrm{~mm}$ in group 1; and two patients have mucosal thickening above 10 $\mathrm{mm}$ in group 2 . There was no statistically significant difference for mucosal thickness between group 2 and group 3 ( $p=0.864$ ) (Table 3 ).

Right and left maxillary sinus volumes and mucosal thicknesses were also compared. There were no statistical differences between groups according to right and left comparisons ( $p=0.462$ ). Left maxillary mucosal thickening was prominent in group 1 compared to right maxillary thickening but there was no statistical difference $(p=0.18)$.

Table 1. Detailed information about gender, reason of bisphosphonates treatment, duration of drug administration and stages of the medication-related osteonecrosis of the jaw of the study patients

\begin{tabular}{|c|c|c|c|c|c|}
\hline Patient & Gender & Diagnosis & Duration of BP therapy & Localization of BRONJ & Stage \\
\hline 1 & Male & Prostate $\mathrm{Ca}$ & 48 months & Maxilla & 2 \\
\hline 2 & Female & Breast Ca & 36 months & Maxilla & 3 \\
\hline 3 & Male & Prostate $\mathrm{Ca}$ & 36 months & Maxilla & 2 \\
\hline 4 & Female & Breast Ca & 12 months & Maxilla & 2 \\
\hline 5 & Male & Prostate $\mathrm{Ca}$ & 48 months & Maxilla & 2 \\
\hline 6 & Female & Osteoporosis & 1 months & Maxilla & 2 \\
\hline 7 & Male & Prostate $\mathrm{Ca}$ & 36 months & Maxilla & 2 \\
\hline 8 & Male & Prostate $\mathrm{Ca}$ & 60 months & Maxilla & 3 \\
\hline 9 & Female & Breast Ca & 12 months & No necrosis & - \\
\hline 10 & Male & Lung Ca & 18 months & No necrosis & - \\
\hline 11 & Female & Osteoporosis & 48 months & No necrosis & - \\
\hline 12 & Male & Prostate $\mathrm{Ca}$ & 48 months & No necrosis & - \\
\hline 13 & Male & Prostate $\mathrm{Ca}$ & 60 months & No necrosis & - \\
\hline 14 & Female & Endometrium Ca & 36 months & No necrosis & - \\
\hline 15 & Male & Multiple myeloma & 42 months & No necrosis & - \\
\hline 16 & Female & Osteoporosis & 48 months & No necrosis & - \\
\hline 17 & Male & Pancreas Ca & 24 months & No necrosis & - \\
\hline
\end{tabular}


Table 2. The mean maxillary sinus volumes as $\mathrm{mm}^{3}$ and mucosal thickenings as $\mathrm{mm}$ of the patients. The data are expressed as mean \pm standard deviation values. $n$ indicates the sinus numbers in each groups

\begin{tabular}{|l|l|l|l|l|l|l|}
\hline & $\begin{array}{l}\text { Right maxillary } \\
\text { sinus volumes }\end{array}$ & $\begin{array}{l}\text { Left maxillary } \\
\text { sinus volumes }\end{array}$ & $\begin{array}{l}\text { Total maxillary } \\
\text { sinus volumes }\end{array}$ & $\begin{array}{l}\text { Right mucosal } \\
\text { thickening }\end{array}$ & $\begin{array}{l}\text { Left mucosal } \\
\text { thickening }\end{array}$ & $\begin{array}{l}\text { Total mucosal } \\
\text { thickening }\end{array}$ \\
\hline Group 1 & $\begin{array}{l}11335 \pm 1793 \\
(n=8)\end{array}$ & $\begin{array}{l}8590 \pm 2178 \\
(n=8)\end{array}$ & $\begin{array}{l}9700 \pm 1375.66 \\
(n=16)\end{array}$ & $\begin{array}{l}2.081 \pm 0.83 \\
(n=8)\end{array}$ & $\begin{array}{l}8.909 \pm 7.09 \\
(n=8)\end{array}$ & $\begin{array}{l}5.920 \pm 5.94 \\
(n=16)\end{array}$ \\
\hline Group 2 & $\begin{array}{l}11371 \pm 1837 \\
(n=9)\end{array}$ & $\begin{array}{l}9225 \pm 1619 \\
(n=9)\end{array}$ & $\begin{array}{l}11498 \pm 3979.80 \\
(n=18)\end{array}$ & $\begin{array}{l}1.627 \pm 1.72 \\
(n=9)\end{array}$ & $\begin{array}{l}2.09 \pm 1.03 \\
(n=9)\end{array}$ & $\begin{array}{l}1.718 \pm 2.58 \\
(n=18)\end{array}$ \\
\hline Group 3 & $\begin{array}{l}9461 \pm 1965 \\
(n=10)\end{array}$ & $\begin{array}{l}10914 \pm 2142 \\
(n=10)\end{array}$ & $\begin{array}{l}13114 \pm 1271.26 \\
(n=20)\end{array}$ & $\begin{array}{l}1.343 \pm 0.76 \\
(n=10)\end{array}$ & $\begin{array}{l}1.23 \pm 0.28 \\
(n=10)\end{array}$ & $\begin{array}{l}1.265 \pm 0.83 \\
(n=20)\end{array}$ \\
\hline
\end{tabular}

Table 3. Statistical comparisons of mucosal thickenings between groups. $P$ value $<0.05$ was significant

\begin{tabular}{|l|l|l|l|}
\hline \multirow{2}{*}{ Comparisons } & \multicolumn{2}{|l|}{ Mean mucosal thickness } & P value \\
\hline \multirow{2}{*}{ Group 1-Group 2 } & Group 1 $(\mathrm{n}=16)$ & Group 2 $(\mathrm{n}=18)$ & \multirow{2}{*}{ 0.049* } \\
\cline { 2 - 4 } & $5.92 \mathrm{~mm}$ & $1.71 \mathrm{~mm}$ & \multirow{2}{*}{$0.021^{*}$} \\
\hline \multirow{2}{*}{ Group 2-Group 3 } & Group 1 $(\mathrm{n}=16)$ & Group 3 $(\mathrm{n}=20)$ & \multirow{2}{*}{0.864} \\
\cline { 2 - 3 } & $5.92 \mathrm{~mm}$ & $1.26 \mathrm{~mm}$ & \\
\hline *: One-way ANOVA, Tukey test & Group 2 $(\mathrm{n}=18)$ & Group 3 $(\mathrm{n}=20)$ & \\
\cline { 2 - 4 } & $1.71 \mathrm{~mm}$ & $1.26 \mathrm{~mm}$ & \\
\hline
\end{tabular}

\section{Discussion}

Nitrogen-containing BPs as zoledronic acid are now widely used because they are more effective at inhibiting bone resorption (13). The etiopathology of MRONJ has not been explored in detail in an upto-date manner. The reduced bone remodeling in MRONJ patients is related to induced inhibition of osteoclasts; and osteogenic cells depend on the dose of the medication (14), but effects of BPs on oral soft tissues are still controversial.

BPs are known to inhibit the viability, proliferation and migration of oral keratinocytes and fibroblast via the mevalonate pathway $(13,15)$. Cell culture studies have demonstrated that nitrogen-containing BPs can inhibit angiogenesis (16-18). However, it is not obvious if this is a result of BPs changing the expression of angiogenic receptors on the endothelial cells or an alteration in the generation of growth factors by fibroblasts or other cells (13).

In addition, recent studies concluded that, calcium potentiates the cytotoxic effects of BPs $(12,19)$. It is thought that stored BPs in the epithelium may be released while soft tissues sustain traumatic damages such as tooth extraction, and this affects the nearby cells, even basal keratinocytes and fibroblasts, and impairs mucosal healing, and leads to MRONJ (12). In this study, all patients were selected from patients who were treated with IV nitrogen-containing BPS (Zoledronate).

Even development of MRONJ was found to be related on a dose-dependent manner (1-3), one of the maxillary MRONJ patient had only one-month zoledronate therapy. This may suggest that the etiopathogenesis of MRONJ is not only associated with drug mechanism, but also related with personal genetic background (20).

The management of the patients with MRONJ remains controversial but AAOMS suggest determining the treatment modalities according to the stage of MRONJ. At early stages, prevention from necrosis and symptomatic therapy with medications such as antimicrobial or anti-inflammatory drugs are recommended. In advanced stages, infection and pain control and surgical debridement/resections should be beneficial for the management of the disease (21). Patients in this study were treated with medical and surgical treatment modalities according to AAOMS suggestions. Eight patients had stage 2 MRONJ and superficial debridement of necrotic area was performed to all patients and analgesics, 
antimicrobial drugs and chlorhexidine mouthwashes were prescribed for infection control. However, two patients had stage $3 \mathrm{MRONJ}$ and these patients were treated with surgical resection of the necrotic part of the jaw addition to medical treatment.

Although clinical examination is favored for diagnosis of MRONJ primarily, imaging is essential for determining the extent of the lesion and diagnosing at early stages. Recent studies focus on early detection of MRONJ from conventional radiographs or tomography scans, and some authors have reported that CBCT can detect early structural changes in a more predictive way than conventional radiographs $(22,23)$. In this study, three-dimensional CBCT scans of the patients were evaluated.

Several reports concluded that the mandible is affected more frequently than the maxilla in MRONJ cases $(6-9,24)$. There are few studies published in the literature that focus on evaluating the maxillary sinus involvement due to maxillary MRONJ (10-12).

A case control study reported by Gallego et al. (12), evaluated the mucosal thickening of the maxillary sinus from panoramic and CT images of patients with mandibular and maxillary MRONJ. The study showed that the thickening of the maxillary sinus membrane was more prominent in MRONJ patients than healthy individuals. In this study, the authors evaluated the maxillary MRONJ patients and BPs treated patients separately, compared them with healthy individuals; and found that, maxillary MRONJ patients had significantly prominent mucosal thickening than BPs treated non-necrotic patients and healthy subjects $(p=0.001)$. This result could be the reason of tissue response to necrosis in maxilla rather than the direct effect of BPs. Because, in the comparison of BPs treated non-necrotic patients and healthy individuals, there were no significant differences in mucosal thickening $(p=0.864)$.

On the other hand, sinus mucosa could be removed from the underlying bone without significant force in patients treated with BPs, which is similar to the oral mucoperiosteum (10). There is a hypothesis in the literature that soft tissue adjacent to bone is affected more by BPs than soft tissue that is not in connection with bone (25). It is known that, periosteal membrane is connected to the underlying bone with collagenous; and the inhibitory action of BPs on fibroblasts and epithelial cells may be the reason of the easier detachment of the periost and Schneiderian membrane. It could be the reason of the thickening in the sinus mucosa nearer to bony lesion in maxillary MRONJ patients in group 1.

To authors' knowledge, this study is the first report in the literature that evaluates maxillary sinus volumes of MRONJ patients by using three-dimensional CBCT. There are no statistically differences between MRONJ patients and healthy individuals $(p=0.153)$.

\section{Conclusion}

BPs can affect the oral hard and soft tissues and MRONJ can be easily diagnosed with CBCT. There are significant changes in maxillary sinus mucosal thickening in MRONJ patients with maxillary lesions. The exact mechanism of BPs on soft tissues is still controversial; however, it can be thought that BPs affect the fibroblast's apoptotic and proliferative activities, and this may lead osteonecrosis of oral soft tissues. According to results of this study, the mucosal thickening and volume reducing may be the result of the site of MRONJ instead of direct affect of BPs to sinus membrane. Furthermore, there are some limitations of this study. This study was carried out in few patients. Nevertheless, some patients were excluded from the study because of inappropriate CBCT images for the evaluation of maxillary and paranasal sinuses. Further studies with more patients are suggested to reach certain results.

\section{Disclaimer Statements}

The authors reported no potential conflict of interest. There were no contributor or funder in this study. This study was presented as a poster in $9^{\text {th }}$ ACBID International Congress, May 2016, Antalya, Turkey.

\section{Ethics}

Ethics Committee Approval: This retrospective cohort study followed the Declaration of Helsinki on Medical Protocol and Ethics; and the Local Ethics Committee of Erciyes University (Kayseri, Turkey) approved (decision no: 2016/25, date: 08.01.2016).

Informed Consent: An informed consent was obtained from all patients.

Peer-review: Externally peer-reviewed.

\section{Authorship Contributions}

Surgical and Medical Practices: A.A., E.K., Concept: C.Y.A, Design: Z.B.G., Data Collection or Processing: 
E.F.A., Analysis or Interpretation: C.Y.A., Literature Search: C.Y.A., Writing: C.Y.A.

Conflict of Interest: No conflict of interest was declared by the authors.

Financial Disclosure: The authors declared that this study received no financial support.

\section{References}

1. Ruggiero SL, Dodson TB, Assael LA, Landesberg R, Marx RE, Mehrotra B, et al. American Association of Oral and Maxillofacial Surgeons position paper on bisphosphonate-related osteonecrosis of the jaws--2009 update. J Oral Maxillofac Surg 2009; 67: 2-12.

2. Nussbaum SR, Younger J, Vandepol CJ, Gagel RF, Zubler MA, Chapman $R$, et al. Single-dose intravenous therapy with pamidronate for the treatment of hypercalcemia of malignancy: comparison of 30-, 60-, and 90-mg dosages. Am J Med 1993; 95 : 297-304.

3. Delmas PD, Meunier PJ. The management of Paget's disease of bone. N Engl J Med 1997; 336: 558-66.

4. Letocha $A D$, Cintas $H L$, Troendle JF, Reynolds JC, Cann CE, Chernoff EJ, et al. Controlled trial of pamidronate in children with types III and IV osteogenesis imperfecta confirms vertebral gains but not short-term functional improvement. J Bone Miner Res 2005; 20: 977-86.

5. Maurer P, Sandulescu T, Kriwalsky MS, Rashad A, Hollstein S, Stricker I, et al. Bisphosphonate-related osteonecrosis of the maxilla and sinusitis maxillaris. Int J Oral Maxillofac Surg 2011; 40: 285-91.

6. Bamias A, Kastritis E, Bamia C, Moulopoulos LA, Melakopoulos I, Bozas $\mathrm{G}$, et al. Osteonecrosis of the jaw in cancer after treatment with bisphosphonates: incidence and risk factors. J Clin Oncol 2005; 23: 8580-7.

7. Bagan JV, Murillo J, Jimenez Y, Poveda R, Milian MA, Sanchis JM, et al. Avascular jaw osteonecrosis in association with cancer chemotherapy: series of 10 cases. J Oral Pathol Med 2005; 34: 120-3.

8. Marx RE, Sawatari Y, Fortin M, Broumand V. Bisphosphonateinduced exposed bone (osteonecrosis/osteopetrosis) of the jaws: risk factors, recognition, prevention, and treatment. J Oral Maxillofac Surg 2005; 63: 1567-75.

9. Ruggiero SL, Mehrotra B, Rosenberg TJ, Engroff SL. Osteonecrosis of the jaws associated with the use of bisphosphonates: a review of 63 cases. J Oral Maxillofac Surg 2004; 62: 527-34.

10. Voss PJ, Vargas Soto G, Schmelzeisen R, Izumi K, Stricker A, Bittermann $G$, et al. Sinusitis and oroantral fistula in patients with bisphosphonate-associated necrosis of the maxilla. Head Face Med 2016; 12: 3.

11. Mast G, Otto S, Mücke T, Schreyer $C$, Bissinger $O$, Kolk A, et al. Incidence of maxillary sinusitis and oro-antral fistulae in bisphosphonate-related osteonecrosis of the jaw. J Craniomaxillofac Surg 2012; 40: 568-71.
12. Gallego L, Junquera L, Pelaz A, García-Consuegra L, AlvarezArenal A, Costilla S. Sinus mucosal thickening in bisphosphonaterelated osteonecrosis of the jaws: a case-control study. ORL J Otorhinolaryngol Relat Spec 2014; 76: 199-206.

13. Ohlrich EJ, Coates DE, Cullinan MP, Milne TJ, Zafar S, Zhao Y, et al. The bisphosphonate zoledronic acid regulates key angiogenesisrelated genes in primary human gingival fibroblasts. Arch Oral Biol 2016; 63: 7-14.

14. Lam DK, Sándor GKB, Holmes HI, Evans AW, Clokie CML. A review of bisphosphonate-associated osteonecrosis of the jaws and its management. J Can Dent Assoc 2007; 73: 417-22.

15. Bae S, Sun S, Aghaloo T, Oh J-E, McKenna CE, Kang MK, et al. Development of oral osteomucosal tissue constructs in vitro and localization of fluorescently-labeled bisphosphonates to hard and soft tissue. Int J Mol Med 2014; 34: 559-63.

16. Ferretti G, Fabi A, Carlini P, Papaldo P, Cordiali Fei P, Di Cosimo $S$, et al. Zoledronic-acid-induced circulating level modifications of angiogenic factors, metalloproteinases and proinflammatory cytokines in metastatic breast cancer patients. Oncology 2005; 69: 35-43.

17. Fournier P, Boissier S, Filleur S, Guglielmi J, Cabon F, Colombel $M$, et al. Bisphosphonates inhibit angiogenesis in vitro and testosterone-stimulated vascular regrowth in the ventral prostate in castrated rats. Cancer Res 2002; 62: 6538-44.

18. Wood J, Bonjean $K$, Ruetz $S$, Bellahcène $A$, Devy L, Foidart $J M$, et al. Novel antiangiogenic effects of the bisphosphonate compound zoledronic acid. J Pharmacol Exp Ther 2002; 302: 1055-61.

19. Arai N, Inoue S, Tomihara K, Tsuno H, Noguchi M. In vitro synergistic effects of zoledronic acid and calcium on viability of human epithelial cells. Oral Dis 2013; 19: 200-5.

20. Choi H, Lee JH, Kim HJ, Park W, Lee J-H, Kim J-H. Genetic association between VEGF polymorphisms and BRONJ in the Korean population. Oral Dis 2015; 21: 866-71.

21. Ruggiero SL, Dodson TB, Fantasia J, Goodday R, Aghaloo T, Mehrotra B, et al. American Association of Oral and Maxillofacial Surgeons position paper on medication-related osteonecrosis of the jaw--2014 update. J Oral Maxillofac Surg 2014; 72: 1938-56.

22. Olutayo J, Agbaje JO, Jacobs R, Verhaeghe V, Velde FV, Vinckier F. Bisphosphonate-Related Osteonecrosis of the Jaw Bone: Radiological Pattern and the Potential Role of CBCT in Early Diagnosis. J Oral Maxillofac Res 2010; 1: e3.

23. Wilde F, Heufelder M, Lorenz K, Liese S, Liese J, Helmrich J, et al. Prevalence of cone beam computed tomography imaging findings according to the clinical stage of bisphosphonaterelated osteonecrosis of the jaw. Oral Surg Oral Med Oral Pathol Oral Radiol 2012; 114: 804-11.

24. Thumbigere-Math V, Sabino MC, Gopalakrishnan R, Huckabay S, Dudek AZ, Basu S, et al. Bisphosphonate-related osteonecrosis of the jaw: clinical features, risk factors, management, and treatment outcomes of 26 patients. J Oral Maxillofac Surg 2009; 67: 1904-13.

25. Coxon FP, Thompson K, Roelofs AJ, Ebetino FH, Rogers MJ. Visualizing mineral binding and uptake of bisphosphonate by osteoclasts and non-resorbing cells. Bone 2008; 42: 848-60. 